\title{
Character Education In Cultural Sipakatau (Philosophy-Sociological Study In Bugis Communities)
}

\author{
Muhammad Tang ${ }^{* 1}$, Abdul Rahim ${ }^{2}$ \\ ${ }^{I^{*}}$ Sekolah Tinggi Agama Islam (STAI) Al-Furqan Makassar, Indonesia \\ ${ }^{2}$ Institut Agama Islam Negeri (IAIN) Bone, Indonesia \\ *e-mail: I ${ }^{*}$ muhammadtang.mt78@gmail.com²rahimilmi72@gmail.com
}

\begin{abstract}
This paper will analyze, interpret and describe character education found in Sipakata culture or become the basis or basis in the development of character education. Character education in society is very important to be developed based on or based on local culture. The method used in this study is a qualitative type with field-based philosophical-sociological approach, with a Bugis community research locus in Barang village Soppeng district, South Sulawesi Province, Inodonesia. This study reveals that character education found in the Sipakatau Culture, including; mutual respect and respect, advise each other, love and love each other, support each other and protect, help / help each other, and have the same human rights before the Almighty God. These values become the foundation in the development of character education which can be applied in society with three stages of planting, namely; the first stage; moral knowling (understanding the meaning contained in the cultural values of Sipakatau), the second stage; moral feeling (feeling the benefits of these values), and the third stage, namely moral action; after feeling the benefits of this value there is encouragement or motivation to make behavior (action) in everyday life. So that these values are embedded in the soul of the community.
\end{abstract}

Keywords - Character education, Sipakatau culture, Bugis community

\section{INTRODUCTION}

Ancient Greek philosophy gave the meaning of education as an effort to help humans become human. The starting point of the process of "helping to become human" has a deep enough meaning and a holistic and integrative approach is needed. The meaning of "being human" is meant here to be a complete human being. describes that a whole person is a human who develops along with his mind and heart; spiritual and physical; morals and skills. This description illustrates that in humans there are two elements that we need to develop through education, namely physical (physical) and nonphysical (spiritual) elements [1].

The existence of education to develop these two elements, starting from the classical system until the modern-postmodern era today has given rise to various kinds of theories to help humans become fully human. In classical times Plato (427-347 BC) has offered how to develop or educate humans by describing it as pulling a train drawn by two horses, namely the white horse (soul) and the dark horse (lust) and a coachman (reason). The two horses must be balanced so that the train (human) can run well. In line with this, modern theories gave rise to [2], which was formulated by Benjamin S. Bloom on cognitive domains; Krathwohl, Bloom, and Bertram B. Massia developed affective domains, and Simpson perfected them on psychomotoric 
domains known as the development of three shutter in education, namely, affective shutter, cognitive shutter and psychomotor shutter.

However, when looking at the reality of modern human life today; many phenomena that injure human values or humans out of their nature as humans. For example, same-sex marriage (male to male or vice versa female fellow women) that can threaten the sustainability of human life. How can humans develop / give birth to a generation of the next generation if they don't marry or marry their gender opponents, either naturally or with the help of technological tools. Other creatures outside of humans, for example; nonexistent animals that marry same-sex like modern humans today. Another phenomenon that can threaten the essence of humanity is the outbreak of drug abuse (drugs) that can damage human reason. The spread of AIDS is a result of intercourse and free sex that is not a married couple. Increased suicides, especially in developed countries. For example, in 2018 in Japan suicides in adolescents (SD-SMP-SMA) consisted of 250 cases. (Bisnis.com, accessed on 2/19/2019), South Korea and the United States) is also a phenomenon that injures humanitarian values.

These phenomena are a reflection and reflection for the author to give a contribution of thought in solving the problems of modern human life that have come out of nature as human beings. Humans as social beings who are not separated from the life of society who have customs, traditions and culture as wealth that needs to be explored, developed and preserved which can be a grounding in the development of education. The Bugis community or people are one of the tribes that inhabit the island of Sulawesi, especially in South Sulawesi, which is known to have a wealth of customs, traditions and culture. Among them are the Sipakatau culture, "humanizing humans", which has philosophical meanings that need to be analyzed, interpreted and described as the basis for the development of character education.

Furthermore, after these values have been extracted, interpreted, analyzed, and described as the basis for the development of character education; this paper is also present to see how to plant the values of character in the community that can be applied in the cultivation of character values in students in schools / madrasas. 


\section{METHOD}

To develop the foundation for the development of character education found in Sipak culture or humanistic philosophical-sociological studies are needed. Philosophical studies are needed to examine the nature of human beings as subjects as well as objects of education and also become an analytical knife to understand the meaning of Sipakatau culture that grows and develops in Bugis society. While the sosilological study is needed to see the reality in Bugis society about practicing and planting the values of the culture of Sipak or in living his life and life.

Then the theoretical basis used in exploring, analyzing, interpreting and describing the values contained in Sipakatau culture or by using a theory of cultural value orientation (velue-orientation), developed in their book entitled Variations in Value Orientation which is the result of their research. The theory in question is a cultural value orientation theory that sees that the highest values in each culture of human life are at least five things, namely; (1) human nature (meaning of human life), (2) man nature (meaning of human relations with the surrounding environment), (3) time (human perception of time), (4) activity (meaning of work, work, and deeds) humans), (5) relational (human and human relations).

While the theory used in planting values in character education is a theory developed by Lickona [3], that in instilling character values in education through three stages, namely; (1) moral knowledge, (2) moral feeling, (3) moral action. This research is the result of the development of the author's research on the theme "Multicultural Islamic Education in Sipakatau Culture (Ethnographic Study in Social Transformation)", by taking a research locus in Barang village Soppeng district, South Sulawesi Province, Indonesia.

\section{RESULTS}

\section{A. The Nature of Character Education}

To reveal meaning in depth (nature) character education must be seen in various perspectives. Etymologically, the word character (English: character) comes from Greek (greek), namely charassein which means "to engrave". The word "to engrave" can be translated carving, painting, carving, or scratching [5]. While in the Oxpord Dictionary the meaning of "character" has meaning, (1) the mental and moral qualities of individual distinctiveness, (2) a person in a novel, play, or film, (3) a printed or written letter or symbol, (4) chief biology characteristic, which is one that helps in the identification of a species. Indonesian Language Dictionary the word "character" is defined by character, psychological traits, morals or character that distinguish someone from others, and character.

The etymological descriptive gives the terminological meaning that "character (Ing.)" Is a mental and moral attitude (character, morals, and manners) which is the psychological traits possessed by each individual and becomes a differentiator among other individuals. People with character means people who have personality, behavior, character, character, or character. With meaning like this, the character is identical to personality or 
morals. Personality is a characteristic or characteristic or characteristic of a person that comes from the formations received from the environment, for example the family in childhood, and also from birth [4].

gives a description of the character "A reliable inner disposition to respond to situations in amorally good ways." Furthermore, Lickona added, "Character has conceived three interrelated parts: moral knowing, moral feeling, and moral behavior". The Large Indonesian Language Dictionary (provides a formula that character is a form of character, character, character that is inherent in someone's personality which is formed from the results of internalization that are used as a basis for thinking and behaving thus giving rise to a characteristic in that individual. Individual characters will develop well, if they get the right reinforcement, namely in the form of education.

Character can be embedded well in the soul of an individual if through good education too, namely education that is holisitic and integrative. The purpose of holistic education here is education that can touch and develop in a parallel and balanced manner throughout the educational shutter, namely aperture shutter, cognitive shutter and psychomotor shutter. While the meaning of integrative education is education that can integrate educational centers in accordance with the concept of Ki Hajar Dewantara Tri Education Center, namely; family education, school education, and education in the community. This is what will be further explored in the next sub-discussion on character education found in the Sipakatau culture of the Bugis community in South Sulawesi, Indonesia.

\section{B. The meaning and value of the culture of sipakatau}

Sipak or comes from the word "tau" which gets the prefix "paka" and suffixes "si". The word "tau" can be interpreted as a human being, as a human form itself from the body and spirit. Sipakatau said, if it was parsed from the prefix, Si-Paka-tau each contained its own meaning. "Si" can be interpreted as a fellow while "paka" can mean respecting others. So Sipak or mutual respect for fellow humans. Thus the slug or can mean mutual respect with one another. Other meanings can be mutual respect and love for one another.

Argues that in Sipak's conception or embedded meaning, value and everything that is propriety, negative norms are highly respected. Sipak or is any real behavior of a person or group of people who interact in society. [6], explained in descriptive detail about the meaning of Sipakatau, namely;

Sipakatau is a word that has a philosophical meaning that is very deep and can be translated in various kinds of meanings: Respect, support each other, protect each other, guide each other, share with each other, give and receive, interpret something as it is and a myriad of meanings that need to be explored and appointed to the surface as a manifestation of equality of human rights originating from one namely God Almighty.

To reveal, interpret and describe the values of the culture of Sipak or by applying the concept that there are five main or important things in human life, namely; human nature, man nature, time, activity, and relation. So this 
can be identified in the formulation or concept of the Sipakatu culture; that the Sipakatau culture is a culture of "humanizing humans", which has the values contained therein, namely; (a) mutual respect and respect, (b) remind each other / advise each other, (d) love and love each other, (e) support each other and protect each other, (f) give and receive / help each other, and (g) equality human rights before God.

Seeing these values contained in Sipakatau culture is something that is very essence in human beings and there is a concordance of concepts or theories revealed by Kluckhohn \& Strodtbeck. These values will become the foundation in the development of character education that is discussed in this paper.

\section{Source and Cultivation of Sipakatau Cultural Values in the Bugis Society}

Bugis or Bugis people in the Barang village of Soppeng district are a small part of the Bugis community in the South Sulawesi Province. The Bugis or Bugis people are one of the various ethnic groups in Southeast Asia with a population of more than six million, precisely 6. 359700 people, [7]. The Bugis inhabit the Southwestern part of Sulawesi Island with its main location in southern Sulawesi, which is spread in several districts, namely; Maros district, Pangkep district, Barru district, Pare-Pare city, Sidrap district, Wajo district, Bone district, Soppeng district, Pinrang district, Sinjai district and Bulukumba district. In addition to South Sulawesi, Bugis tribes have also spread to several regions in Indonesia, such as; Kalimantan, Sumatra, Ambon and other areas.

The Bugis community or tribe is very well known still adhering to customs, traditions and culture and religious teachings. This was acknowledged [7] explaining that the Bugis people with Ace, Melayu, Banjar, Sunda, Madura, and of course Makassar people were considered to be among the Indonesian people who were the strongest and most firm in their religious teachings (Islam ) Customs, traditions and the whole system of norms or values that developed in the Bugis tribe are known as panggaderen. Panggadereng can also be interpreted as a whole norm that regulates how a person must behave towards his fellow human beings and towards his social institutions reciprocally, giving rise to the dynamics of society.

Explained that the system of leadership was built or developed from the five main elements that exist in Bugis society, namely; (1) ade ', (2) talk, (3) fragile, (4) wari', and (5) sara '. The term Ade 'is associated with the meaning of "adat", which means all social norms and values which include individuals and society. The term ade 'or adat is the genus of the species wari term' (rules about standards, protocols, and who has the right to inherit the throne of the king), rapang (rules that have been determined after comparing with customs in neighboring countries, or comparing decisions which has been taken (including jurisprudence), and comparisons of adat in general, while the term is spoken, that is, rules relating to the judiciary in a broad sense, then the term sara ', meaning the rules that originate from the teachings of religion (Islam). , "There is 'sara sanding', sara 'coupled with the Book of Allah (al-Qur'an \& 
al-Hadith). That is to say, in the Bugis community the source of the adat is sara' (shari'a), and the Shari'a comes from the book of Allah swt. 'an and alHadith).

Ade '(culture) Sipakatau is one of ade' which is a culture in Bugis society to organize and live their lives both as individual beings and as social beings (society). Ade 'Sipakatu is a culture that belongs to Bugis people to respect and respect their fellow human beings regardless of their ethnic, racial, national or religious background. The Sipakata culture originates from the Bugis philosophy known as the $3 \mathrm{~S}$ philosophy (Sipakatau, Sipakalebbih, Sipakainge). This philosophy originally originated from the distinctive personality of the Bugis people, siri'-pesse, which can be interpreted as selfesteem to maintain the dignity and dignity of a Bugis man. [8].

Then how are these traditional and cultural values embedded and developed in the community? The process of developing cultural values in society through the educational process occurs in three places / spaces which are referred to as the Tri Education Center (family environment, school environment and community environment). This also happened in Bugis communities in Barang village, as explained by one of the village community leaders in Barang;

"That in order to instill cultural values with the community, at the school level we respond to government programs regarding the planting of character values to students; at the level / in the family environment of early planting in children; and in the community the community leaders are exemplary examples (uswah) for the other general public ".

explains that the cultivation of moral or good values towards society through three stages, namely: (1) moral knowing, (2) moral feeling, and moral action. The application of the theory revealed by Lickona illustrates that to inherit a good value including the cultural values of the community through the stage of recognition of good and bad values for children, when children do things that are good or useful based on their knowledge, they feel happy and happy, and vice versa when the child makes a mistake, he feels sorry or agitated, because there is a moral knowing of children from the beginning of good and bad values and being able to feel (moral feeling) the benefits and risks, it will be embedded in the moral action of things good and avoiding bad things, both for himself and for others.

\section{Strategy for the Development of the Sipakata or Culture-Based Character Education}

Cultural value in society is a repertoire or wealth owned by a nation that needs to be explored and preserved through character education. To develop cultural values, especially the cultural values of Sipak or through character education, a strategy needs to be in order to be internalized properly. Character education in its essenceis a process of recognizing oneself to protect and respect human dignity. The values contained in Sipakatau culture or in essence are values that contain human dignity or humanize humans. So, 
it is very relevant to be the foundation or basis in the development of character education. Character education based on Sipakatau culture which has a philosophical meaning of a process that "humanizes humans", by having the main character values, namely; mutual respect and respect, advise each other, love and love each other, support each other and protect, accept and give / help, and have the same human rights before God.

The character education based on the Sipakatau culture has universal values, regardless of the background of differences in race, ethnicity, nation and religion. So that character-based culture education in Sipakatau can be implemented in all ethnic groups and religions in any part of the world. It is only possible that different methods or techniques of implementing these values are different, for example; Arabs and Europeans and Westerners differ in respecting and respecting other people or foreigners. But mutual respect and respect is shared by all ethnic groups in this world. For this reason, the strategy to implement character education based on the Sipakatau culture has differences among ethnic groups. If the character education based on Sipakatau culture can develop well in the family environment and school environment, it can also develop well in the community environment. In essence, the three education centers must work together in instilling and developing character education based on the cultural values of Sipak or. So that people can create a high value or dignity of humanity as the core or the main goal of character education based on the culture of Sipakatau.

\section{IV.CONCLUSION}

Education is a process of helping humans become whole human beings, or in other words education is a process of humanizing humans. Humans as subjects as well as objects of education have their existence and main role in developing education. Education that can achieve and maintain the dignity of human values. Education that needs to be developed to achieve this goal is character education that is extracted from humans or the community itself. Humans as social creatures have culture as a vehicle to build their civilization. Humans or Bugis people are one of the Indonesian ethnic groups that have a diversity of cultures in developing their communities.

Humans or Bugis people are very well known for their hospitality towards others, regardless of the background of differences in race, ethnicity, nation and religion. It is this attitude that transforms into the philosophy of his life, which is humanity's attitude. Therefore, this attitude has become a philosophy of life for people or Bugis people in living their lives in community, nation and state; then this philosophy becomes a culture known as Sipakatau culture (humanizing humans). This culture that was explored and developed in this paper became the basis or basis of character education. Character education based on Sipak culture or which has the meaning that education is humanizing humans by having the main character, namely; human beings who respect and respect each other, advise each other, love and love each other, support each other and protect, give and receive (help), and have the same human rights in front of God Almighty. 


\section{REFERENCES}

[1] Al-Qardhawi, M. Yusuf. Pendidikan Islam dan Madrasah Hasan AlBanna, terj. Bustani A. Gani dan Zainal Abidin Ahmad, Jakarta: Bulan Bintang, 1980.

[2] Bogdan, Robert C. dan Sari Knopp Biklen, Qualitative Research For Education an Introduction Theories and Methods, Boston: Ally and Bacon Inc, 1992.

[3] Lickona, Thomas, Educating For Character How Our School Can Teach Respect and Responsbility, New York: Bantam Books, 1992.

[4] Doni Koesoema A. Pendidikan Karakter: Strategi Mendidik Anak di ZamanGlobal. Jakarta: Grasindo, 2007.

[5] Echols, John M. dan Hassan Shadily, Kamus Inggris Indonesia. Jakarta: Gramedia, 1987

[6] Maula, Amiruddin, Demi Makassar, Renungan dan Pikiran, Makassar: Global Publishing, 2001.

[7] BPS., Kewarganegaraan, Suku Bangsa, Agama dan Bahasa Sehari-Hari Penduduk Indonesia: Hasil Sensus th. 2010, Jakarta: Badan Pusat Statistik, 2010.

[8] Said, Mashadi., Konsep Jati Diri Manusia Bugis Dalam Lontara: Sebuah Telaah Falsafi Tentang Kebijaksanaan Hidup Bugis, disertasi, IKIP Malang, 1998. 